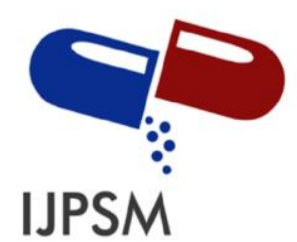

Emelia Septina et al, Int. Journal of Pharmaceutical Sciences and Medicine (IJPSM), Vol.5 Issue. 12, December- 2020, pg. 1-10

ISSN: 2519-9889

Impact Factor: 3.426

\title{
Overview of Traditional Use, Phytochemical, and Pharmacological Activities of Chinese Petai (Leucaena leucocephala)
}

\author{
Emelia Septina $^{1}$; Rina Desni Yetti ${ }^{1}$; Harrizul Rivai ${ }^{2 *}$ \\ ${ }^{1}$ College of Pharmacy (STIFARM), Jl. Raya Siteba Kurao Pagang, Padang 25147, Indonesia \\ ${ }^{2}$ Faculty of Pharmacy, Andalas University, Limau Manih Campus, Padang 25163, Indonesia \\ "Email: harrizul@yahoo.co.id and harrizul@ phar.unand.ac.id \\ DOI: 10.47760/ijpsm.2020.v05i12.001
}

\begin{abstract}
Various herbal remedies have been used in multiple medical systems for the treatment and management of numerous diseases. One of the herbs found in Indonesia is Chinese petai. This article aims to seek information about the traditional uses, phytochemicals, and the Chinese petai plant (Leucaena leucocephala). The way to find information is through Google Scholar with the keywords "Leucaena leucocephala," "traditional use," "phytochemicals," "pharmacological activity." The Chinese petai plant (Leucaena leucocephala) has been used in various traditional medicinal systems to treat multiple human diseases. Phytochemically, this plant has been reported to contain numerous alkaloids, flavonoids, saponins, tannins, and triterpenoids. Pharmacologically this plant has been reported as antibacterial, antidiabetic, anti-inflammatory, anticancer, anthelmintic, antioxidant, and larvicide. There are also reports available for this plant's traditional use as useful as a worm medicine, smooth bowel movements, treating fractures, insomnia, swelling, kidney inflammation, diabetes, and smooth menstruation. Many of the constituents isolated from (Leucaena leucocephala) have pharmacological activity, supporting further pharmacological studies.
\end{abstract}

Keywords: Chinese petai, Leucaena leucocephala, traditional use, phytochemical, pharmacological activity.

\section{Introduction}

Chinese petai is a tree with the botanical name Leucaena leucocephala. Chinese petai is one of the most versatile types of legumes planted in mixed cropping patterns. Other uses are living fences, firebreaks, windbreaks, green lines, and live vines for twisted plants such as pepper, vanilla, passion fruit, and shade trees in coffee and cocoa plantations. In Chinese petai forests, it is often planted as intercropping to control erosion and increase soil fertility. The roots of Chinese petai have root nodules where nitrogen bind and produce leaves as an organic source. Chinese petai trees are up to $20 \mathrm{~m}$ tall but mostly around 2-10 $\mathrm{m}$. The branches are low, and many units are brown or grayish in color, rash, and jellyfish. The components are round thoracic, with tight hair ends. The leaves are compound and pinnate in shape, the fins number 3-10 pairs, mostly with glands on the leaf shaft just before the base of the lower fin; small lever, triangular shape. Leaflets per fin 5-20 pairs, opposite, longitudinal profile, 6-16 (-21) $\mathrm{mm} \times 1-2(-5) \mathrm{mm}$, with pointed tips and oblique base (not the same), smooth hair surface, and frayed edges. The flowers are compound in the form of long-stemmed humps gathered in panicles containing 2-6 heads; each head is composed of 100-180 flower buds, forming a white or yellowish ball 12-21 mm in diameter, on a 2-5 cm long stalk. Small flowers, number-5; bell-shaped petal tube with short teeth, about $3 \mathrm{~mm}$; the crown of solitary shape, approx. $5 \mathrm{~mm}$, detachable. Ten strands of stamens, approximately $1 \mathrm{~cm}$, loose. The pods are straight ribbons, flat and thin, 14-26 cm $\times 2 \mathrm{~cm}$, with gaps between the seeds, green and finally greenish-brown or dark brown when dry when ripe, breaking themselves apart throughout the seam. The Chinese Petai fruit contains 15-30 seeds, located transversely in the legume, in the 


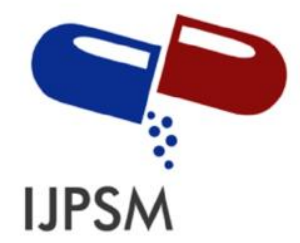

Emelia Septina et al, Int. Journal of Pharmaceutical Sciences and Medicine (IJPSM), Vol.5 Issue. 12, December- 2020, pg. 1-10

ISSN: 2519-9889

Impact Factor: 3.426

form of an oval breach or inverted egg, with a shiny dark brown color measuring $6-10 \mathrm{~mm} \times 3-4.5 \mathrm{~mm}$. The seeds are similar to petai but smaller in size and smaller in appearance.[1] The morphology of Chinese petai (Leucaena leucocephala) is presented in Figure 1.[2]
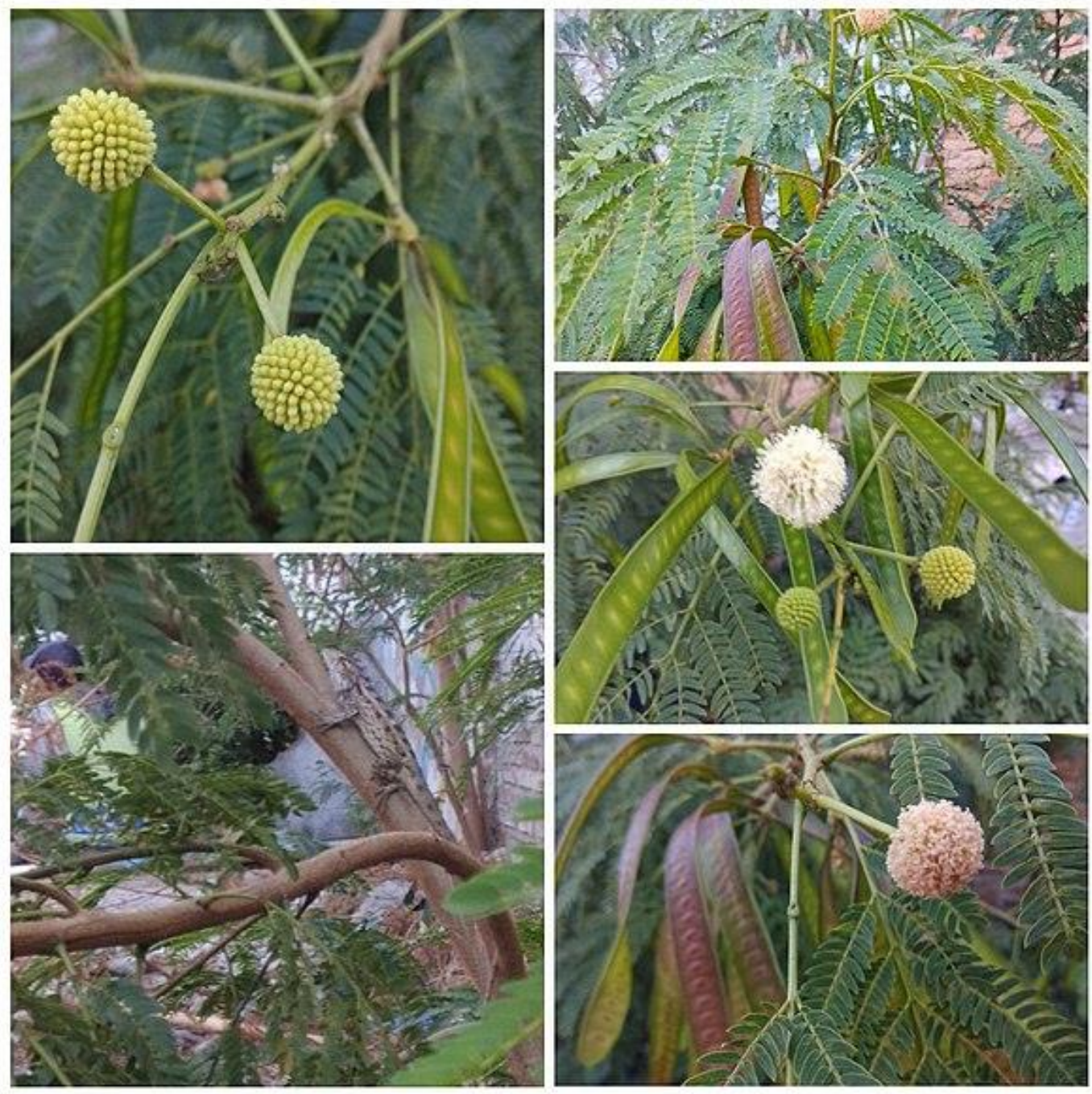

Figure 1: Morphology of Chinese petai (Leucaena leucocephala) [2]

\subsection{Scientific classification[3]}

Kingdom: Plantae

(unranked): Angiosperms

(unranked): Eudicots

(unranked): Rosids

Order: Fabales

Family: Fabaceae

Subfamily: Caesalpinioideae

(unranked): Mimosoid clade

Genus: Leucaena 


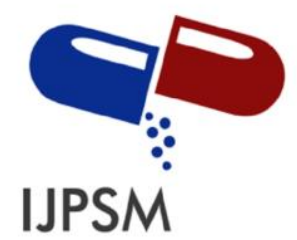

Emelia Septina et al, Int. Journal of Pharmaceutical Sciences and Medicine (IJPSM), Vol.5 Issue. 12, December- 2020, pg. 1-10

ISSN: 2519-9889

Impact Factor: 3.426

Species: L. leucocephala

Binomial name: Leucaena leucocephala (Lam.) de Wit

Synonyms:

- Acacia frondosa Willd.

- Acacia glauca (L.) Willd.

- Acacia leucocephala (Lam.) Link

- Acacia leucophala Link

- Leucaena glabra Benth.

- Leucaena glauca Benth.

- Mimosa glauca sensu L.1763 Misapplied

- Mimosa glauca Koenig ex Roxb.

- Mimosa leucocephala Lam.

- Mimosa leucophala Lam.

\section{Research Methods}

\subsection{Data Collection}

In compiling this review article, the technique used is to use literature studies by finding sources or literature in primary data or the state of official books and international journals in the last 20 years (2000-2020). In making this review article, data search using online media with keywords is Leucaena leucocephala, traditional use, phytochemical, and pharmacology. Search for the primary references used in this review article through trusted websites such as ScienceDirect, NCBI, ResearchGate, Google Scholar, and other published and reliable journals.

\section{Traditional Use}

Chinese petai has often been used as traditional medicine for Indonesians, especially the leaves and seeds. [4] Chinese petai leaves or lamtoro (Leucaena leucocephala (Lam) de Wit), contain active flavonoids that can reduce pain.[4] Chinese petai seeds (Leucaena leucocephala) in traditional medicine have anthelmintic properties, insomnia, swelling, kidney inflammation, and diabetes. With concentrations of $10 \%, 15 \%$, and 20 $\%(\mathrm{w} / \mathrm{v})$ ethanol extract of Chinese petai seeds, they have an anthelmintic effect.[6]

Chinese petai leaves (Leucaena leucocephala) are more effective in healing grade II burns in terms of their content, adaptation to the environment, processing, efficiency, affordability, and society availability as a complementary therapy.[7] Chinese petai (Leucaena leucocephala) is a plant commonly used by people as a wound medicine. Its use is traditionally chosen because it has no side effects of irritating the skin.[8]

\section{Phytochemical Review}

The ethanol extract of Chinese petai leaves contains saponins, tannins, flavonoids, and steroids/triterpenoids. The ethanol extract obtained from the stems of Chinese petai indicated alkaloids, tannins, saponins, and sterols/triterpenoids. Meanwhile, the seeds' ethanol extract states saponins, tannins, and steroids/triterpenoids.[9]

The phytochemical test of L. leucocephala showed the presence of terpenes, flavonoids, coumarin, and sterols. Various parts of L. leucocephala have medicinal properties. The flavonoid constituents were isolated from the chloroform, ethyl acetate, and n-butanol fractions of aqueous alcohol extract. The phytochemical properties of Leucaena leucocephala were identified as caffeic acid, isorhamnetin, chrysoberyl, isorhamnetin 3-Ogalactoside, kaempferol-3-O-arabinoside, quercetin-3-O-rhamnoside, and luteolin-7-glucoside.[8]

Another study revealed that in Leucaena leucocephala, there are phylobatins, alkaloids, cardiac glycosides, tannins, and glycosides (reducing sugars and glycosides) in the presence of flavonoids and saponins.[11]

GC-MS analysis of L. leucocephala leaves showed 30 compounds, and the main chemical constituents were squalene (41.02\%), phytol (33.80\%), 3,7,11,15-Tetramethyl-2-hexadecane-1 -ol. (30.86\%) and 3,7,11- 


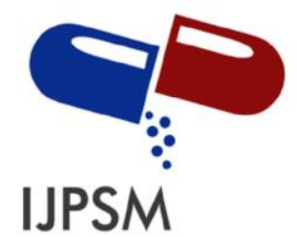

\section{Emelia Septina et al, Int. Journal of Pharmaceutical Sciences and Medicine (IJPSM), Vol.5 Issue. 12, December- 2020, pg. 1-10}

Tridecatrienenitrile, 4,8,12-trimethyl (25.64\%). Some of these compounds have been reported to have various biological activities such as antioxidants, antimicrobials, hepatoprotective, antiparasitic, insecticides, nematicides, pesticides, anti-coronary, antiarthritic, antiandrogenic, hypocholesterolemic, cancer prevention, anticancer, analgesic, anesthetics, allergens, etc. This study shows that the leaves of L. leucocephala have various potential bioactive compounds and are recommended as plants with phytopharmaceutical interests.[12] Leucaena leucocephala (Lam.) De Wit (Petai Grasshopper) is a medium plant in a tropical plant group that can survive in hot, dry, and warm environments. In Malaysia, plants are available in abundance. Since none of them have been used commercially, and there is no serious intention of discovering the benefits of $L$. leucocephala, this work came up with the idea of analyzing the antioxidants contained in plant leaves by undergoing different extraction methods and chemical testing. The phytochemical tests carried out in this study were antioxidant activity using the diphenylpicrylhydrazyl free radical (DPPH) method, total phenol levels using the Folin-Ciocalteu method, total flavonoid levels using a colorimetric test with ascorbic acid and quercetin were used as reference standards. Phosphorus analysis used the blue molybdenum method or also known as the ascorbic acid method. For an antioxidant activity with the diphenylpicrylhydrazyl free radical (DPPH) method, a higher concentration was recorded by extraction using methanol (dry sample), namely $8247.0 \mathrm{mg} / \mathrm{L}$. For total phenol content, a higher concentration was recorded by extraction using deionized water (dry sample), which was $4276.0 \mathrm{mg} / \mathrm{L}$. For the total flavonoid content using the colorimetric test, a higher concentration was recorded by extraction using methanol (dry sample), which was $4439.0 \mathrm{mg} / \mathrm{L}$. The phosphorus analysis at a higher concentration was recorded with extraction using methanol (dry sample) is $71.057 \mathrm{mg} / \mathrm{L} .[13]$

An ecological route and virtue for the fabrication of copper oxide nanoparticles (CuONPs) using Leucaena leucocephala $\mathrm{L}$. leaf extract at room temperature were reported. Phytochemical screening of fresh aqueous leaf extract revealed tannins, saponins, coumarin, flavonoids, cardiac glycosides, steroids, phenols, carbohydrates, and amino acids. Copper oxide nanoparticles prepared at the Nanoscale. Their morphology and size were characterized using field emission scanning electron microscopy. Energy-dispersive X-ray spectroscopy, transmission electron microscopy, X-ray diffraction, Fourier transform infrared spectroscopy, BrunauerEmmett-Teller, analysis Barrett-Joyner-Halenda, and Photoluminescence. Furthermore, CuO-NP exhibits remarkable antimicrobial, antimalarial, and antimycobacterial activity against selected human pathogens.[15]

\section{Pharmacological Review}

\subsection{Analgesic Activity}

Lamtoro leaves or known as Chinese petai (Leucaena leucocephala (Lam) de Wit), contain flavonoid active substances that can reduce pain. This study aims to determine whether there is an analgesic effect of lamtoro leaf extract at doses of $0.54 \mathrm{~g}, 0.72 \mathrm{~g}$, and $1.08 \mathrm{~g}$ in male white mice. The subjects of this study were 15 male white mice, which were divided into five groups, namely the negative control group (CMC 1\%), the positive control group (Paracetamol), and the treatment group (lamtoro leaf extract). The analgesic effect was tested by applying heat stimulation at a temperature of $55^{\circ} \mathrm{C}$. The observed response of mice was in the form of licking and jumping. Observations were made for 1 minute. Comments were made before giving the test substance, then at 30,60,90, and 120 minutes. The results showed that the extract of lamtoro leaves at doses of $0.54 \mathrm{~g}$, $0.72 \mathrm{~g}$, and $1.08 \mathrm{~g}$ had an analgesic effect on male white mice. Thus, it can be concluded that the extract of lamtoro leaves has an analgesic effect on thermally induced male white mice.[5]

\subsection{Antibacterial Activity}

The ethanol extract of Chinese petai leaves (Leucaena leucocephala) using the agar diffusion method against Staphylococcus aureus and Escherichia coli at concentrations of $20 \%, 40 \%, 60 \%, 80 \%$, and $100 \%$ resulted in an inhibition zone $(6.0 \mathrm{~mm}, 6.0 \mathrm{~mm}, 7.2 \mathrm{~mm}, 10.2 \mathrm{~mm}, 15.4 \mathrm{~mm})$ and $(6.0 \mathrm{~mm}, 6.0 \mathrm{~mm}, 7.0 \mathrm{~mm}, 7.4 \mathrm{~mm}$, $12.2 \mathrm{~mm}$ ), respectively. The positive control tetracycline $\mathrm{HCl}$ showed the inhibition zone $38.0 \mathrm{~mm}$.[15] The ethanol extract of $96 \%$ Chinese petai leaves (Leucaena leucocephala) using the disk diffusion method has antibacterial activity against Staphylococcus aureus at concentrations of $25 \%, 50 \%, 75 \%$, and $100 \%$ resulting in inhibition zones of 10,525 mm, 11,475 mm, 12,725 mm, and $16.85 \mathrm{~mm}$, respectively.[16] 


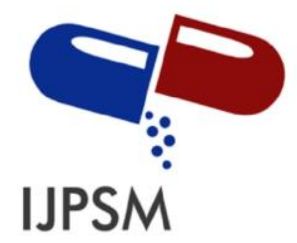

\section{Emelia Septina et al, Int. Journal of Pharmaceutical Sciences and Medicine (IJPSM), Vol.5 Issue. 12, December- 2020, pg. 1-10}

ISSN: 2519-9889

Impact Factor: 3.426

\subsection{Antidiabetic Activity}

The enzymes $\alpha$-amylase and $\alpha$-glucosidase in the digestive process will hydrolyze starch to glucose. If the blood glucose exceeds the normal limit (>140 mg/dL), then a person is diagnosed with diabetes mellitus. Treatment of diabetes mellitus, especially type 2 , is usually treated using the drug acarbose, which will inhibit $\alpha$-amylase and $\alpha$-glucosidase. In this study, the inhibition ability of infusion from fresh and dry Chinese petai fruit (Leucaena leucocephala L. de Wit) will be analyzed against these two enzymes. The \% inhibition of infusion to the $\alpha$-amylase enzyme activity was determined using the 3,5-dinitrosalicylic acid (DNS) method. For $\alpha$-glucosidase, using the substrate p-nitrophenyl-a-D-glucopyranoside (p-NPG). The absorbance of the reaction was measured using a microplate reader at a wavelength of $530 \mathrm{~nm}$ for $\alpha$-amylase and $410 \mathrm{~nm}$ for $\alpha$ glucosidase. The dry sample of Chinese petai stated that the $\%$ inhibition of infusion was better than the fresh sample in inhibiting the activity of the $\alpha$-amylase enzyme with the following percentages: fruit infusion of dried Chinese petai was $92.54 \pm 1.11 \%$, this value was not significantly different from Acarbose $93.89 \pm 0.02$ $\%$. While the $\%$ inhibition of the $\alpha$-glucosidase enzyme activity from all samples had a significant difference with Acarbose $(\mathrm{P}<0.05)$ with an inhibition value of $97.99 \pm 0.19 \%$. These results indicate that the Chinese petai plant has the potential as an antidiabetic, especially in inhibiting the $\alpha$-amylase enzyme activity.[17]

Diabetes mellitus is a disease in which secretion is disturbed due to decreased sensitivity and damage to beta cells. The purpose of this study was to prove that the extract of Chinese petai leaves (Leucaena leucocephala (Lam.) de Wit) has the activity of reducing blood sugar levels of hyperglycemic mice at an effective dose. This antihyperglycemic study used 30 white mice. The antihyperglycemic activity test was carried out in six treatment groups, namely group I (normal control), group II (negative control, alloxan induction $200 \mathrm{mg} / \mathrm{kg}$ BW and distilled water), group III (alloxan induction and glibenclamide $10 \mathrm{mg} / \mathrm{kg} \mathrm{BW}$ ), group IV ( alloxan induction and Chinese petai leaf extract $200 \mathrm{mg} / \mathrm{kg} \mathrm{BW}$ ), group V (alloxan induction and Chinese petai leaf extract $400 \mathrm{mg} / \mathrm{kg} \mathrm{BW}$ ), group VI (alloxan induction and Chinese petai leaf extract $300 \mathrm{mg} / \mathrm{kg} \mathrm{BW}$ ). All treatment groups were given this treatment for 14 days and measured blood sugar levels on days $0,3,10$, and 17. The antihyperglycemic activity of Chinese petai leaf extract was shown by calculating the hypoglycemic power of each treatment. The results showed that the ethanol extract of Chinese petai leaves had antihyperglycemic activity in alloxan-induced mice. The test dose of ethanol extract of Chinese petai leaves of $600 \mathrm{mg} / \mathrm{kg} \mathrm{BW}$ had an effective antihyperglycemic activity compared to $400 \mathrm{mg} / \mathrm{kg} \mathrm{BW}$ and $200 \mathrm{mg} / \mathrm{kg} \mathrm{BW}$, comparable to the positive control group.[18]

One oral antidiabetic agent that can reduce the increase in postprandial blood glucose levels is an $\alpha$-glucosidase inhibitor. Chinese petai seeds (Leucaena leucocephala (Lam,) de Wit) is traditionally used as antidiabetic. The purpose of this study was to determine the in vitro antidiabetic activity of the ethanol extract of leaves, bark, and Chinese petai seeds. The ethanol extract was made by maceration in $96 \%$ ethanol. The antidiabetic activity test was carried out by extract inhibition on the action of the $\alpha$-glucosidase enzyme with p-nitrophenyl$\alpha$-D-glucopyranoside as a substrate and quercetin as a positive control. The ethanol extract of Chinese petai bark, leaves, and seeds showed inhibitory activity on the $\alpha$-glucosidase enzyme with IC50 $33.75 \mu \mathrm{g} / \mathrm{mL}$, IC50 $132.55 \mu \mathrm{g} / \mathrm{mL}$, and $3659 \mu \mathrm{g} / \mathrm{mL}$.[9]

This research was conducted to determine the hypoglycemic and hypolipidemic properties of Phyllanthus acidus, Leucaena leucocephala, and Psidium guajava leaf extracts. The extract at a $250 \mathrm{mg} / \mathrm{kg}$ dose was administered to streptozotocin-induced diabetic rats $(65 \mathrm{mg} / \mathrm{kg})$ orally and daily for eight weeks. Blood glucose levels, body weight, hematologic values, lipid profiles, blood chemistry, and serum insulin were examined. The antioxidant activity of the extract was also assessed using the 1,1-diphenyl-2-picryl-hydrazine (DPPH) radical. scavenging test. Also, to see whether the extract had acute toxicity, after administering the oral extract at doses of 1000, 1500, and $2000 \mathrm{mg} / \mathrm{kg}$ was carried out on healthy mice. The results showed that the extract significantly ( $\mathrm{p}<0.05$ ) decreased blood glucose levels, total cholesterol (TC), triglycerides (TG), low-density lipoprotein (LDL), blood urea nitrogen (BUN), and creatinine. But increased high-density lipoprotein (HDL) and serum insulin in mice treated with diabetes. However, the hematologic values including white blood cells (WBC), red blood cells (RBC), hemoglobin ( $\mathrm{Hb})$, hematocrit (Hct) in normal and diabetic mice were not affected by the extract. DPPH test results showed that the leaf extracts of P. acidus, L. leucocephala, and P. guajava had an antioxidant activity with EC50 values $232.37 \pm 15.27,296.10 \pm 16.40$, and $39.40 \pm 3.82$ 


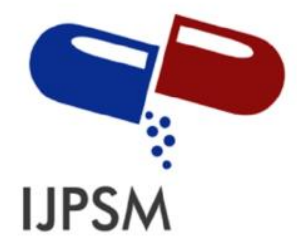

\section{Emelia Septina et al, Int. Journal of Pharmaceutical Sciences and Medicine (IJPSM), Vol.5 Issue. 12, December- 2020, pg. 1-10}

$\mu \mathrm{g} / \mathrm{mL}$, which was less potent than ascorbic acid $(1.48 \pm 0.86 \mu \mathrm{g} / \mathrm{mL})$. Also, extracts at doses up to $2000 \mathrm{mg} / \mathrm{kg}$ did not show signs of acute toxicity and death of rats in the observation period.[19]

Antidiabetic test research on the active fraction of methanol extract of Leucaena leucocephala (Lmk) DeWit seeds was carried out using alloxan-induced rats. Fractionation was carried out on the active fraction using column chromatography. The most active fraction in previous studies was analyzed by thin-layer chromatography (TLC) using the mobile phase chloroform-methanol (5: 1), chloroform-methanol (2: 1), chloroform-methanol-water $(5: 5: 1)$ on the resulting isolates. by oral glucose tolerance test and identification. The findings indicated that methanolic extract had greater antidiabetic activity, and five isolates from methanol extract isolation. The results of identifying bioactive compounds in the form of glycosides with galactose monosaccharide groups and many other saccharides. It was concluded that the active fraction of Leucaena leucocephala (Lmk) DeWit seeds had antidiabetic activity and the bioactive compounds were glycosides with galactose monosaccharide groups and many other saccharides.[20]

Leucaena leucocephala was traditionally used to treat diabetes. This study was designed to evaluate the in vitro "insulin-like" activity of Leucaena leucocephala (Lam.) de Wit. Dilute fruit extracts on lipid and glucose metabolism. The extract's ability to stimulate adipogenesis, inhibit lipolysis, and activate radiolabeled glucose uptake was assessed using primary mouse adipocytes. Real-Time Quantitative RT-PCR was carried out to investigate the effect of extracts on gene expression levels (protein kinase B, AKT; glucose transporter 4, GLUT4; hormone-sensitive lipase, HSL; phosphatidylinositol-3-kinase, PI3KA; sterol regulatory elementbinding factor 1, Srebp1 ). It is involved in the insulin-induced signaling pathway. L. leucocephala aqueous fruit extract stimulates moderate adipogenesis and glucose uptake into adipocytes compared to insulin. Generally, the extract exerts an appreciable lipolytic effect at lower concentrations but decreases gradually higher concentrations. This finding is in line with the RT-PCR analysis. The expression of GLUT4 and HSL genes was upregulated twofold and one fold, while the AKT, PI3KA, and Srebp1 genes were downregulated. The aqueous fruit extract of L. leucocephala could be used as an adjuvant in treating type 2 diabetes mellitus and weight management due to its increased glucose uptake and balanced adipogenesis lipolysis properties.[21]

This study aims to increase the evidence of Chinese petai seed extract (Leucaena leucocephala) on postprandial blood glucose levels in alloxan-induced diabetic male rats. This research is an experiment with a pretest-posttest control group design. This study's subjects were 25 white male rats with Wistar strain, which were divided into five groups. Group I as a positive control was given Acarbose, group II as a negative control, and group III, group IV, and group V as the treatment group and given white lead tree seed extract $1.5 \mathrm{~g} / \mathrm{kg}$ $\mathrm{BW}, 3.5 \mathrm{~g} / \mathrm{kg} \mathrm{BW}$, and $7.8 \mathrm{~g} / \mathrm{kg} \mathrm{BW}$, respectively. Blood glucose levels were checked before and two hours after treatment. Statistical analysis used one-way ANOVA and Bonferroni post hoc tests. The results showed no significant difference between group III, group IV, and group V and the positive control group $(\mathrm{p}<0.05)$. The best result of inhibition of increasing blood glucose was found in the dose group of $7.8 \mathrm{~g} / \mathrm{kg} \mathrm{BW}$ (group V) with an average difference of $186.4 \mathrm{mg} / \mathrm{dL}$. In conclusion, Chinese petai seed extract can reduce blood glucose levels two hours postprandial in white male alloxan-induced rats, and a dose of $7.8 \mathrm{~g} / \mathrm{kg} \mathrm{BW}$ proved to be the most effective.[22]

Leucaena leucocephala (Lmk) De Wit is known as a traditional medicine to treat degenerative diseases such as diabetes, liver degeneration, kidney failure, etc. This study aimed to examine the effect of L. leucocephala extract in streptozotocin-induced diabetic rats. Blood glucose, regeneration of pancreatic islets, serum lipids in streptozotocin-induced diabetic rats were assessed on days $0,3,7$, and 14 after injection of streptozotocin as a cause of diabetes. The results showed that the extract could inhibit the increase in blood glucose and lipid levels and significantly increase the number of pancreatic islets per unit area $(p<0.05)$ for 14 days. It can be concluded that L. leucocephala seed extract acts as a hypoglycemic agent by regenerating beta cells of pancreatic beta cells damaged by streptozotocin. Pancreatic $\beta$ cells are also protected from the necrotic effects of streptozotocin.[23]

\subsection{Anti-Diarrheal Activity}

In diarrhea induced by castor oil, L. leucocephala seed extract at doses of 100,200 , and $400 \mathrm{mg} / \mathrm{kg} \mathrm{BW}$ has been shown to slow down the onset of diarrhea significantly. Reduce diarrhea frequency, stool weight, and 


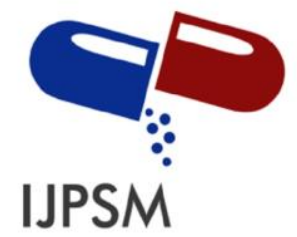

\section{Emelia Septina et al, Int. Journal of Pharmaceutical Sciences and Medicine (IJPSM), Vol.5 Issue. 12, December- 2020, pg. 1-10}

ISSN: 2519-9889

Impact Factor: 3.426

diarrhea duration compared to $\mathrm{Na}$ CMC as a negative control ( $<<0.05$ ). The extract at a $400 \mathrm{mg} / \mathrm{kg} \mathrm{BW}$ dose was not significantly different from loperamide as a positive control ( $\mathrm{p}>0.05)$. In this study, L. leucocephala extract reduced the gut travel distance of Chinese ink only at a dose of $400 \mathrm{mg} / \mathrm{kg} \mathrm{BW}$, which had activity comparable to loperamide significantly. The ethanol extract of $L$. leucocephala seed has an anti-diarrheal activity, supporting its use in traditional medicine.[24]

\subsection{Anti-Inflammatory Activity}

A wound is a part of the tissue that comes from the body's tissues damaged. The injury is characterized by the breakdown of continuity of cells, which is then followed by healing. Wound healing is a complex process consisting of inflammatory processes, reepithelialization, wound contraction, and collagen metabolism. Many natural resources in Indonesia are currently used as traditional medicine, one of which is the Chinese petai leaves (Leucaena glauca). Chinese petai is believed to be used as an anti-inflammatory drug in treating cuts. Its main content is saponins, which are proven to be used as compounds capable of spurring collagen formation. This structural protein plays a role in the wound healing process and the ability to be a cleanser, effectively healing open wounds. Scientists with the method used have proven it is the maceration method. The maceration method was carried out to determine the effectiveness of Chinese petai leaf extract using $70 \%$ ethanol. Based on the research, it can be concluded that the leaves of Chinese petai (Leucaena glauca) have high effectiveness and are believed to have properties in dealing with anti-inflammatory in swollen wounds.[25]

The anti-inflammatory activity test was carried out using the artificial inflammation formation method on the soles of the feet of male white mice. The research was conducted using 15 mice divided into five treatment groups with criteria aged 2-3 months with a weight of 20-30 g. Tests were carried out using three different lamtoro seed extract doses, namely $200 \mathrm{mg} / 20 \mathrm{~g} \mathrm{BW}, 400 \mathrm{mg} / 20 \mathrm{~g} \mathrm{BW}$, and $600 \mathrm{mg} / 20 \mathrm{~g} \mathrm{BW}$. Based on the research, it was found that the largest percentage of inflammation was at a dose of $200 \mathrm{mg} / 20 \mathrm{~g} \mathrm{BW}$, and the smallest portion of inflammation was at a dose of $600 \mathrm{mg} / 20 \mathrm{~g} \mathrm{BW}$. The data on the measurement of the size of inflammation were statistically tested using the LSD method. The $200 \mathrm{mg} / 20 \mathrm{~g} \mathrm{BW}$ dose group results did not have potential anti-inflammatory properties. The $400 \mathrm{mg} / 20 \mathrm{~g}$ BW dose group and the $600 \mathrm{mg} / 20 \mathrm{~g} \mathrm{BW}$ dose had potential anti-inflammatory properties.[26]

\subsection{Anticancer Activity}

Chinese petai and jengkol are leguminous plants containing natural compounds such as alkaloids, flavonoids, saponins, tannins, and triterpenoids. These natural compounds have the potential to act as anticancer. The extraction process uses the maceration method with $70 \%$ ethanol solvent. The cytotoxicity method used was the MTT assay with MCF-7 breast cancer cell culture and HeLa cervix. The parameter measured is the IC50 value. The combination of Chinese petai leaf extract and jengkol bark with a ratio of $1: 0,0: 1,1: 1,1: 3,1: 5$, 1: 7 and 1: 9 shows the activity of the IC50 value on MCF-7 respectively of 102,$56 ; 51.76 ; 37.35 ; 28.57$; $11.69 ; 7.5$ and $1.92 \mu \mathrm{g} / \mathrm{mL}$ while in HeLa cells $137.65 ; 39.62 ; 20.91 ; 14.46 ; 9.34 ; 7.28$ and $1.86 \mu \mathrm{g} / \mathrm{mL}$. All comparisons fall into the category of cytotoxicity except the 1: 1 ratio in MCF-7 cancer cells.[27]

Oral cancer is one of the most common cancers worldwide, and metastasis is recognized as the main factor causing the low survival rate. Inhibition of metastatic progression and increased survival rates for oral cancer are important research objectives. Leucaena leucocephala has been used as a traditional medicine to treat various disorders. Previous research has demonstrated the antioxidant, anti-inflammatory and anticancer properties of the L. leucocephala plant material. However, the molecular mechanisms underlying the anticancer effects induced by $L$. leucocephala remain unclear. In this study, we investigated the effect of $L$. leucocephala (LLE) extract on SCC-9 and SAS oral cancer cells and examined the potential inhibitory mechanisms involved. The results showed that LLE attenuates the migration and invasion ability of SCC-9 and SAS cells by reducing the activity and expression of proteins from matrix metalloproteinase-2 (MMP-2). Regarding the mitogen-activated protein kinase (MAPK) pathway, phosphorylation of ERK1 / 2 and p38 showed a significant inhibitory effect in the presence of LLE. The application of ERK inhibitor and p38 inhibitor confirms that both signaling transduction pathways are involved in inhibiting cell metastasis. These data suggest that $L$. leucocephala can be a potent therapeutic agent for preventing and treating oral cancer and a major plant source for future anticancer research.[28] 


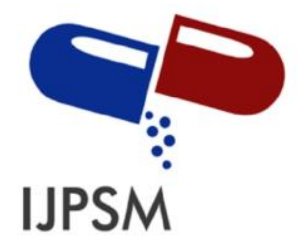

\section{Emelia Septina et al, Int. Journal of Pharmaceutical Sciences and Medicine (IJPSM), Vol.5 Issue. 12, December- 2020, pg. 1-10}

ISSN: 2519-9889

Impact Factor: 3.426

\subsection{Anthelmintic Activity}

The different protein extracts obtained from $L$. leucocephala seeds had different ovicidal effects on $H$. contortus. The ovicidal efficacy of TE $(99.2 \%$ and $56.6 \%$ at 0.8 and $0.4 \mathrm{mg} / \mathrm{mL}$, respectively) was significantly higher in CE $(83.4 \%$ at $0.8 \mathrm{mg} / \mathrm{mL})$. This difference in efficacy in the EC50 values of TE and CE, EC50 CE $(0.48 \mathrm{mg} / \mathrm{mL}, 95 \%$ CI: $0.40-0.57)$ was significantly greater than TE $(0.33 \mathrm{mg} / \mathrm{mL}, 95 \%$ CI: 0.29 0.38). There were several signs of an ovicidal effect on $H$. contortus in the SE test at the concentrations tested. Higher concentrations of TE and CE $(0.6 \mathrm{mg} / \mathrm{mL})$ were tested for effect on $H$. contortus larvae, but rates of cuticle loss after $60 \mathrm{~min}$ did not differ between control (buffer), TE, and CE (98.8\%, $98.2 \%$, and $95.3 \%$, respectively).[29] Ethanol extract of $96 \%$ Chinese petai seeds (Leucaena leucocephala) has anthelmintic activity against roundworms (Ascaridia galli Schrank) at concentrations of $10 \%, 15 \%$, and $20 \%$, with 54.78 $\%$ mortality and $88 \%$. The positive control used mebendazole at $0.5 \%$.[6]

\subsection{Antioxidant Activity}

Extract of Chinese petai seeds (Leucaena leucocephala) using the 1,1-diphenyl-2-picrylhydrazyl (DPPH) test stated that Leucaena leucocephala showed relatively low antioxidant activity. With a sample concentration required for $50 \% \mathrm{DPPH}$ free radical scavenging of $839.56 \pm 37.34 \mu \mathrm{g} / \mathrm{mL}$ compared to vitamin $\mathrm{C}(1.48 \pm 0.07$ $\mu \mathrm{g} / \mathrm{mL}$ ).[30] This study aims to determine the effect of germination time on the antioxidant activity of Leucaena leucocephala (Lmk.) De Wit sprouts. Determination of antioxidant activity was carried out on the ethanol extract of germinated seeds using the $\beta$-carotene bleaching test. The results showed that the duration of germination influenced the antioxidant activity of the germinated seeds. Germination for four days affected the greatest increase in antioxidant activity by 2.78 fold. It caused a significant increase in the total phenol content of $7.29, \beta$-carotene by 3.27 , ascorbic acid by 3.81 , and $\alpha$-tocopherol by 4.58 -fold, compared with the absorbed seeds. Total phenolic content $53.42 \pm 0.22 \mathrm{mg} \mathrm{CAE} / \mathrm{g} \mathrm{DW}, \beta$-carotene $530.99 \pm 71.1310^{-3} \mathrm{mg} / 100 \mathrm{~g}$, ascorbic acid $152.37 \pm 2.06 \mathrm{mg} / 100 \mathrm{~g}$, and $\alpha$-tocopherol $59.27 \pm 0.10 \mathrm{mg} / 100 \mathrm{~g}$ sample. These findings suggest that $L$. leucocephala sprouts can be considered a natural source of antioxidants.[31]

This study aims to identify Leucaena leucocephala leaves' chemical content and evaluate the antioxidant and antimicrobial activity of the extract and its compounds. Acacylated flavonol glycosides, quercetin-3-O- (2"trans-p-coumaryl)- $\alpha$-rhamnopyranosyl-(1" $\rightarrow 6 ")$ - $\beta$-glucopyranoside $\quad(1)$ other than quercetin-3-O- $\alpha$ rhamnopyranosyl-(1"' $\rightarrow \quad 2 ")-\beta$-glucopyranoside $\quad(2)$, quercetin-7-O- $\alpha$-rhamnopyranosyl- $\quad(1 " \rightarrow \quad 2 ")-\beta$ glucopyranoside (3), quercetin-3-O- $\alpha$-rhamnopyranoside (4), quercetin-3-O- $\beta$-glucopyranoside (5), isovitexin (6), vitexin (7) and quercetin (8) were isolated for the first time from Leucaena leucocephala. The antioxidant activity of extracts and isolated compounds $1,3 \& 4$ were evaluated. AcylatedgflavonolFRAP, DPPH, Metal chelating and ABTS test coumaric and (3) recorded the highest antioxidant activity than other extracts and compounds. Extracts and compounds 1, 2, 3, and 5 were studied for their antimicrobial activity. Both extract and compound 1 had significant activity against Gram-negative, moderate to Gram-positive, and Candida bacteria and were inactive against fungi. The structure of the compounds is described based on spectral analysis. L. leucocephala has good antioxidant, antibacterial properties and can function as a free radical inhibitor or scavenger, acting perhaps as a major antioxidant and should be investigated for its antiinflammatory and anticancer activities. [32]

\subsection{Larvicidal Activity}

Chinese petai leaves (Leucaena glauca, Benth) contain saponins, where saponins can be used as larvicides. The purpose of this study was to determine the effectiveness of the ethanol extract of Chinese petai leaves (Leucaena glauca, Benth) as a natural larvicide against the death of larvae of Aedes aegypti instar III. This type of research is an experiment with a post-test only research design with a control group design where there are two groups: the treatment and control groups. A sample of 25 larvae for each group and repeated four times. So that the total sample is 700 Aedes aegypti larvae. The results showed that at a concentration of $0 \%$ (control), ethanol extract of Chinese petai leaves could kill 0 Aedes aegypti larvae, a concentration of $4 \%$ could kill seven larvae (28\%), a concentration of $6 \%$ could kill 18 larvae (72\%), a concentration of $8 \%$ could kill. kill 21 larvae (84\%), $10 \%$ concentration can kill 25 larvae (100\%), $12 \%$ concentration can kill 25 larvae $(100 \%)$, and $14 \%$ concentration can kill 25 larvae $(100 \%)$. Based on the Kruskal Wallis test, it can be concluded that there is an effect of giving ethanol extract of Chinese petai leaves (Leucaena glauca, Benth) on 


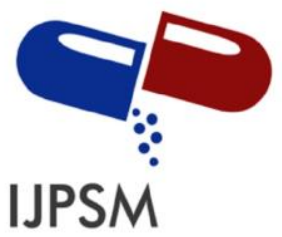

\section{Emelia Septina et al, Int. Journal of Pharmaceutical Sciences and Medicine (IJPSM), Vol.5 Issue. 12, December- 2020, pg. 1-10}

ISSN: 2519-9889

Impact Factor: 3.426

the mortality of larvae of Aedes aegypti instar III with a significant value of $\mathrm{p}=0.000(\mathrm{p}<0.01)$. The ethanol extract of Chinese petai leaves (Leucaena glauca, Benth) at a concentration of $10 \%$ is the smallest concentration that can kill $100 \%$ of Aedes aegypti instar III larvae.[33]

\section{Conclusion}

The Chinese petai plant (Leucaena leucocephala) is a plant rich in chemical compounds distributed in every part of the plant, which has benefits for treating various antibacterial, antidiabetic diseases anti-diarrhea, antiinflammatory, anticancer, anthelmintic, and antioxidant. In recent years, the traditional use of natural compounds, especially Chinese petai, has received much attention because it has been well tested for efficacy and is generally believed to be safe for human use. It is the best classic approach in finding new drugs for the management of various diseases.

\section{References}

[1]. https://id.wikipedia.org/wiki/Lamtoro

[2]. https://upload.wikimedia.org/wikipedia/commons/thumb/7/70/Arya-lamtoro-COLLAGE-2019.jpg/375px-Aryalamtoro-COLLAGE-2019.jpg

[3]. https://en.wikipedia.org/wiki/Leucaena_leucocephala

[4]. https://www.sehatq.com/artikel/manfaat-petai-cina-tanaman-polong-meksiko-yang-populer-di-indonesia

[5]. Ishak M. Uji Efek Analgetik Ekstrak Etanol Daun Lamtoro (Leucaena leucocephala (Lam) de Wit) pada Mencit Putih Jantan (Mus musculus). Pharmacon. 2017 Oct 24;6(4):130-8.

[6]. Umboro RO, Hamdani AS. Uji Daya Anthelmintik Ekstrak Etanol Biji Petai Cina (Leucaena leucocephala, Lmk. de Wit) terhadap cacing gelang (Ascaridia galli schrank) Secara In Vitro. JISIP (Jurnal Ilmu Sosial dan Pendidikan). 2019 Mar 9;3(1):304-10

[7]. Fuadah DZ. Efektivitas Daun Petai Cina (Leucaena leucocephala) dan Daun Jarak Pagar (Jatropha curcas) Terhadap Proses Penyembuhan Luka Bakar Grade II Pada Tikus Putih (Rattus norvegicus). Jurnal Ilmu Keperawatan: Journal of Nursing Science. 2016 Aug 3;4(1):20-33.

[8]. Kurnia ED, Ratnasari D, Helmiawati Y. Pembuatan Gel Ekstrak Daun Petai Cina (Leucaena glauca, Benth) Dengan Basis Gel Lidah (Aloe Vera L.) Buaya Sebagai Obat Luka Terbuka. Journal of Holistic and Health Sciences. 2019 Aug 5;3(1):39-45

[9]. Rachmatiah T, Nurvita H. Potensi Antidiabetes Pada Tumbuhan Petai Cina (Leucaena leucocephala (Lam). De Wit). Sainstech. 2015;25(1):115-8

[10]. Hassan RA, Tawfik WA, Abou-Setta LM. The flavonoid constituents of Leucaena Leucocephala growing in Egypt and their biological activity. African Journal of Traditional, Complementary, and Alternative Medicines. 2014;11(1):67-72.

[11]. Awe FA, Giwa-Ajeniya AO, Akinyemi AA, Ezeri GN. Phytochemical analysis of Acalypha wilkesiana, Leucaena leucocephala, Peperomia pellucida and Senna alata leaves. The International Journal of Engineering and Sciences (IJES). 2013;2(9):41-4.

[12]. Zayed MZ, Samling BE. Phytochemical constituents of the leaves of Leucaena leucocephala from Malaysia. Int J Pharm Pharm Sci. 2016;8(12):174-9.

[13]. Zarina Z, Ghazali CM, Sam ST. Characterization analysis for leaves of Leucaena leucocephala by using phytochemical screening assay. In AIP Conference Proceedings 2017 Sep 26 (Vol. 1885, No. 1, p. 020260). AIP Publishing LLC.

[14]. Aher YB, Jain GH, Patil GE, Savale AR, Ghotekar SK, Pore DM, Pansambal SS, Deshmukh KK. Biosynthesis of copper oxide nanoparticles using leaves extract of Leucaena leucocephala L. and their promising upshot against diverse pathogens. International Journal of Molecular and Clinical Microbiology. 2017 Jun 1;7(1):776-86.

[15]. Retnaningsih A. Uji Daya Hambat Daun Petai Cina (Leucaena leucocephala folium) Terhadap Bakteri Staphylococcus aureus dan Escherichia coli Menggunakan Metode Difusi Agar. Jurnal Dunia Kesmas. 2016;5(2):110-4.

[16]. Valerian A, Girsang E, Nasution SL, Nasution SW. Uji Efektivitas Ekstrak Daun Petai Cina (Leucaena leucocephala) Untuk Menghambat Pertumbuhan Staphylococcus aureus. Jurnal Biosains.;5(2):66-70.

[17]. Sy SD, Nasution MR, Novianty R. Analisis Uji Infusa Buah Petai Cina, Daun Keji Beling Dan Daun Tempuyung Sebagai Inhibitor Enzim A-Amilase Dan A-Glukosidase. Jurnal Riset Kimia. 2019 Mar 30;10(1):44-50 


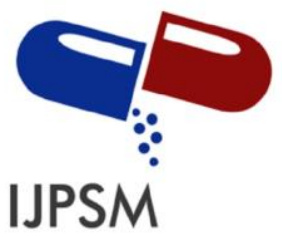

\section{Emelia Septina et al, Int. Journal of Pharmaceutical Sciences and Medicine (IJPSM), Vol.5 Issue. 12, December- 2020, pg. 1-10}

[18]. Widyasti JH, Kurniasari F. Uji Aktivitas Antihiperglikemik Ekstrak Daun Petai Cina (Leucaena leucocephala (Lam.) de Wit) pada Mencit Induksi Aloksan. PHARMACY: Jurnal Farmasi Indonesia (Pharmaceutical Journal of Indonesia). 2019 Sep 19;16(1):107-17.

[19]. Talubmook C, Buddhakala N. Hypoglycemic and hypolipidemic properties of leaf extracts from Phyllanthus acidus (L.) Skeels., Leucaena leucocephala (Lam.) de Wit. and Psidium guajava (L.) in streptozotocin-induced diabetic rats. GSTF Journal of BioSciences. 2013 May 1;2(2):30-4.

[20]. Syamsudin, Sumarny R, Simanjuntak P. Antidiabetic activity of active fractions of Leucaena leucocephala (Lmk) Dewit seeds in the experiment model. European Journal of Scientific Research. 2010;43(3):384-391

[21]. Kuppusamy UR, Arumugam B, Azaman N, Jen Wai C. Leucaena leucocephala fruit aqueous extract stimulates adipogenesis, lipolysis, and glucose uptake in primary rat adipocytes. The Scientific World Journal. 2014 Aug 10;2014:Article ID 737263, 8 pages.

[22]. Pujangga IW, Nainggolan D, Thadeus MS. Effects of Lead tree Seed (Leucaena leucocephala) Extract in Inhibiting the Increase of Postprandial Blood Glucose Level in Alloxan-induced Diabetic Rats. Jurnal Gizi dan Pangan. 2019 Nov 26;14(3):157-64.

[23]. Simnajuntak DS, Simanjuntak P. The effects of Leucaena leucocephala (Lmk) De Wit seeds on blood sugar levels: an experimental study. Int. J. Sci. Res. 2006;2:49-52.

[24]. Husein S, Nainggolan M, Yuandani Y, Fanany I. Evaluation of Antidiarrheal Activity of the Ethanol Extract Leucaena leucocephala (Lam) de Wit Seed. Open Access Macedonian Journal of Medical Sciences. 2020 Apr 25;8(A):278-82.

[25]. Praja MH, Oktarlina RZ. Uji Efektivitas Daun Petai Cina (Laucaena glauca) Sebagai Antiinflamasi Dalam Pengobatan Luka Bengkak. Jurnal Majority. 2017 Feb 1;6(1):60-3.

[26]. Sentat T, Handayani F. Uji Efek Antiinflamasi Ekstrak Etanol Biji Lamtoro (Leucaena leucocephala L.) Terhadap Udem Telapak Kaki Mencit Yang Diinduksi Karagenin. Jurnal Ilmu Kesehatan. 2018 Jul 9;6(1):84-9.

[27]. Noviardi H, Yuningtyas S, Suwarni D. Sitotoksisitas Kombinasi Ekstrak Daun Petai Cina Dan Kulit Jengkol Terhadap Sel Kanker Payudara Dan Serviks (Cytotoxicity of Petai Cina Leaves and Jengkol Pods Combinations Against Breast Cancer Cells and Cervix). Biopropal Industri. 2019 Dec 1;10(2):109-17.

[28]. Chung HH, Chen MK, Chang YC, Yang SF, Lin CC, Lin CW. Inhibitory effects of Leucaena leucocephala on the metastasis and invasion of human oral cancer cells. Environmental toxicology. 2017 Jun;32(6):1765-74.

[29]. Soares AM, Araújo SA, Lopes SG, Costa Junior LM. Anthelmintic activity of Leucaena leucocephala protein extracts on Haemonchus contortus. Revista Brasileira de Parasitologia Veterinária. 2015 Dec;24(4):396-401.

[30]. Chowtivannakul P, Srichaikul B, Talubmook C. Antidiabetic and antioxidant activities of seed extract from Leucaena leucocephala (Lam.) de Wit. Agriculture and Natural Resources. 2016 Sep 1;50(5):357-61.

[31]. Suryanti V, Marliyana SD, Putri HE. Effect of germination on antioxidant activity, total phenolics, $\beta$-carotene, ascorbic acid, and $\alpha$-tocopherol contents of lead tree sprouts (Leucaena leucocephala (Lmk.) de Wit). International Food Research Journal. 2016;23(1):167-72.

[32]. Mohammed RS, El Souda SS, Taie HA, Moharam ME, Shaker KH. Antioxidant, antimicrobial activities of flavonoids glycoside from Leucaena leucocephala leaves. Journal of Applied Pharmaceutical Science. 2015 Jun;5(06):138-47.

[33]. Armadhani R. Keefektifan ekstrak etanol daun petai cina (Leucaena glauca, Benth) sebagai larvasida alami terhadap kematian larva nyamuk Aedes aegypti Instar III (Doctoral dissertation, Universitas Muhammadiyah Surakarta).

\section{A Brief Author Biography}

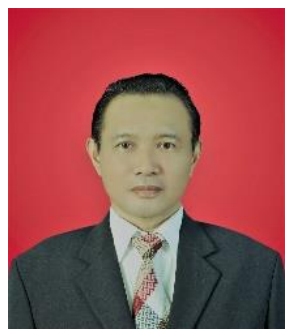

Harrizul Rivai - The Author obtained a bachelor's degree in pharmacy from the Department of Pharmacy, Faculty of Mathematics and Natural Sciences, Padjajaran University, Bandung, a master's degree in science from the Bandung Institute of Technology, and a doctorate from the Department of Chemistry, Faculty of Mathematics and Natural Sciences, Andalas University, Padang. Now the Author is a professor and researcher at the Faculty of Pharmacy, Andalas University, Padang. The Author wrote the book "Principles of Chemical Examination" and translated the book "Pharmaceutical Statistics." The Author has also written articles in various international journals in multiple science fields, such as chemistry, biology, and pharmacy. 